\title{
An Evaluation of the Phytochemical and Nutritional Compositions of Fresh Leaves of Cnidoscolus Aconitifolius [Miller] I.M.Johnston
}

\author{
${ }^{1}$ Chikezie, Uchechukwu Nkeiruka, ${ }^{1}$ Chijioke, Augustine Nsofor, ${ }^{2}$ Adjeroh, \\ Loveth Anayo, ${ }^{1}$ Ogbulie, Toochukwu Ekwutosi, ${ }^{1}$ Udensi, Justina Ugochi, \\ ${ }^{1}$ Oyirioha, Kelechi Chialuka
}

\author{
${ }^{1}$ Department of Biotechnology, Federal University of Technology, Owerri.P.M.B 1526. Owerri,Imo \\ State.Nigeria \\ ${ }^{2}$ Department of Biology, Federal University of Technology, Owerri.P.M.B 1526. Owerri, Imo \\ State.Nigeria \\ uchikezie@yahoo.com
}

\begin{abstract}
Fresh leaves of Cnidoscolus aconitifolius [Miller] I. M. Johnston were analysed for phytochemical and proximate compositions, vitamin and mineral constituents. The phytochemical screening carried out on the fresh leaves revealed the presence of the bioactive compounds; Saponin 3,900mg/100g, Flavonoid $1200 \mathrm{mg} / 100 \mathrm{~g}$, Alkaloid 490mg/100g, Tannins 236mg/100g, Oxalate 873mg/100g, Phenol 11.6mg/100g, Anthraquniones 59mg/100g, Cyanogenic glycoside $24 \mathrm{mg} / 100 \mathrm{~g}$ and Phlobotannins $67 \mathrm{mg} / 100 \mathrm{~g}$. The proximate analysis showed that the fresh leaves contained $1.80 \%$ crude fat, $2.50 \%$ crude fibre, $5.11 \%$ crude protein, $6.54 \%$ carbohydrate, $1.60 \%$ ash and $82.45 \%$ moisture content. The result of the vitamin analysis depicted/revealed that the fresh leaves contained carotene (Vit A) 131.10mg/100g, Ascorbic acid (Vit C)

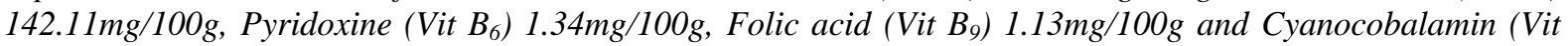
$\left.B_{12}\right) 0.13 \mathrm{mg} / 100 \mathrm{~g}$. The mineral analysis revealed the constituents to be $\mathrm{Mg} 23 \mathrm{mg} / 100 \mathrm{~g}, \mathrm{~K} 102 \mathrm{mg} / 100 \mathrm{~g}, \mathrm{Ca}$ $30.9 \mathrm{mg} / 100 \mathrm{~g}, \mathrm{P} 22 \mathrm{mg} / 100 \mathrm{~g}, \mathrm{Fe} 4.7 \mathrm{mg} / 100 \mathrm{~g}, \mathrm{Cu} 0.5 \mathrm{mg} / \mathrm{lo0g}, \mathrm{Mn} \mathrm{3.2mg/100g}$, Zn $0.3 \mathrm{mg} / 100 \mathrm{~g}$, and $\mathrm{Na}$ $21 \mathrm{mg} / 100 \mathrm{~g}$. These results show that Cnidoscolus aconitifolius is a nutritious green vegetable which can serve as a food supplement and as a medicinal plant.
\end{abstract}

Keyword: Cnidoscolus aconitifolius, phytochemical screening, proximate analysis, mineral and vitamin constituents, nutritional composition, bioactive compounds.

\section{INTRODUCTION}

Cnidoscolus aconitifolius [Miller]I.M.Johnston is a tropical shrub, $3-5 \mathrm{~m}$ tall, distributed throughout most of the Yucatán Penninsula (Abdala - Roberts and Parra - Tabla, 2005). It belongs to the family, Euphorbiaceae, It is commonly known as Chaya or Tree Spinach. The crop originated as a domesticated, leafy green vegetable in the Maya region of Guatemala, Belize and South - east Mexico during pre - Cambrian period (Ross - Ibarra and Molina - Cruz, 2002). It has continued to be used as food, medicine and ornamental plant till date.

C. aconitifolius belongs to a group of arbrescent shrubs. It is an evergreen,drought deciduous shrub, up to $6 \mathrm{~m}$ in height with alternative pinnate lobed leaves, milky sap and small flowers on dichotomously branched cymes. The leaves are large, $32 \mathrm{~cm}$ long and $30 \mathrm{~cm}$ wide on chartacious and succulent petioles (Mordi and Akanji, 2012). This species is monoecious with flowers arranged in inflorescences, with dichotomic ramification, and stalks $15-40 \mathrm{~cm}$ in length (as in C. spinosus: see Bullock, 1982). C. aconitifolius presents glandular trichomes on most of its aerial structures, which produce stinging compounds (L. Abdala - Roberts, pers. obs,). These compounds (i.e. serotonin) have been shown to confer resistance against herbivores (Pollard and Briggs, 1984), and are found in other species of the same genus (e.g. C. texanus, Lookadoo and Pollard., 1991). It is cultivated in domestic gardens rather than in agricultural fields and as such can be used throughout the year (Adeniran et al., 2013).

Due to its ease of cultivation, potential productivity and substantial nutritional value, the plant has spread all over the world, including the tropics. Colloquially the plant is referred to as Chaya (Donkoh 
et al., 1990). In the western part of Nigeria, it is called different names such as Efo Iyana Ipaja and Efo Jerusalem, while in the Niger Delta of Nigeria; it has been nick-named "Hospital Too Far" because of its numerous traditional claims (Mordi and Akanji, 2012), and is also called 'Blood".

Although, the plant is mainly cultivated as food, it has continued to be an important medicinal plant. Much of its recent spread into new areas may likely be attributed to its medicinal value. A wide variety of claims have been made for its medicinal efficacy as a treatment for numerous ailments ranging from its ability to strengthen fingernails and darken grey hair, to cure for alcoholism, insomnia, gout, scorpion stings, brain and vision improvement (Jensen, 1997; Atuahene et al., 1999). It has certain antibacterial properties, as well as a contraceptive effect (Dong et al., 2010). It has been observed in use as diuretic, circulation, and lactation stimulant and has also been recommended for diabetes, obesity, acne, kidney stones and eye problems (Rowe, 1994). Research has shown that $C$. aconitifolius is rich in natural antioxidant (Kuti and Konoru., 2004), which scavenges free radicals. Many chronic diseases and causes of food spoilage are linked to pro-oxidation. Antioxidant components are therefore used in food preservation and drug formulation.(Loliger,1991).

Kuti and Torres (1996) studied the potential nutritional and health benefits of Tree Spinach. Abdala Roberts and Parrra - Tabla (2005) showed that artificial defoliation induces trichome production in the tropical shrub Cnidoscolus aconitifolius (Euphorbiacea). Awoyinka et al., (2007) reported on the phytochemical screening and in vitro bioactivity of Cnidoscolus aconitifolius. Mordi and Akanji (2012) reported the phytochemical screening of the dried leaf extracts of Cnidoscolus aconitifolius and associated changes in liver enzymes, induced by its administration to wistar rats. Adeniran et al., (2013) studied the phytochemical constituents and antimicrobial and antioxidant potentials of Tree Spinach (Cnidoscolus aconitifolius (Miller) I:M. Johnst). The phytochemical screening revealed the presence of secondary metabolites of both preventive and curative importance in medicine, and the presence of compounds with antioxidant activity.

Given its reputed medicinal efficacies and nutritional constituents, the present study evaluates the phytochemical and nutritional compositions of fresh leaves of Cnidoscolus aconitifolius variety found in the locality covered by the research.

\section{Materials AND Methods}

\subsection{Plant Material}

The fresh leaf samples of Cnidoscolus aconitifolius used for this study were obtained from a home garden at Federal Housing Estate, Umuguma, New Owerri in Owerri - west Local Governmet Area, Imo State, Nigeria. The leaves were identified by a taxonomist in the Department of Biology, Federal University of Technology Owerri, Imo State, Nigeria.

\subsection{Phytochemical Analysis}

Phytochemical screening on the sample and subsequent quantification was carried out using the methods described by AOAC (1984), AOAC (1990), Lewis (1974) and Agomuo et al., (2002). Saponins, steroids, phenols, cyanogenic glycosides and phlobotannins were screened for using the methods described by AOAC (1984). Flavonoids and alkaloids were screened using the method of Harborne (1973), as contained in AOAC (1990). The method of Pearson (1976), as described in AOAC (1990), was used for the determination of tannins. Anthraquinones were analysed using the method of Lewis (1974), while oxalate was analysed using the method of Munro and Bassir (1969), as described in Agomuo et al., (2002).

\subsection{Proximate Analysis}

The proximate analysis was carried out on the sample using the methods described by AOAC (1990). Protein content was determined by Kjeldahl method and ash content by ignition at $575 \pm 25^{\circ} \mathrm{C}$ using muffle furnace until sample was carbonized ( about $4 \mathrm{hrs}$ ). Moisture content was determined by drying to constant weight ay $105^{\circ} \mathrm{C}$ in the oven. The crude fat content was determined by soxhlet extraction with petroleum ether as solvent, and crude fibre content by the acid and alkaline digestive method. The carbohydrate content was estimated by difference, subtracting the sum of water, protein, crude fibre and ash percentages from one hundred (percentage).

\subsection{Mineral Analysis}

The AOAC (1990) method was used for the determination of minerals in the test sample. Calcium and magnesium were determined by complexiometric method using EDTA. Potassium and sodium were 
determined by flame photometric method, while copper, zinc, manganese and iron were determined by atomic absorption spectrophotometer (AAS) method. Phosphorus was determined using Spectrophotometer.

\subsection{Vitamin Analysis}

The carotene (Vitamin A) content was determined by the method of the Association of Vitamin Chemists (Kirk and Sawyer, 1998). Pyridoxine $\left(\mathrm{B}_{6}\right)$, Folic acid (B9), and cyanocobalamine $\left(\mathrm{B}_{12}\right)$ were analysed using the method described in AOAC (2005). Ascorbic acid (Vitamin C) was determined by the Barakate Titrimetric method (Barakate et al., 1955).

\section{RESUlTS AND DiscuSSION}

The results obtained from this study show that the fresh leaves of Cnidoscolus aconitifolius contain some bioactive compounds/phytochemicals and have high protein content. They also contain appreciable amounts of essential minerals and vitamins.

\subsection{Phytochemical Analysis}

The result of the phytochemical screening of the extracts of fresh leaves of Cnidoscolus aconitifolus is presented in Table 1. It reveals the presence of saponins, flavonoids, alkaloids, phlobotannins, steroids, anthraquinones and phenols in the ethanolic extract, and the presence of cyanogenic glycosides, tannins and oxalate in the water extract. (Table 1). Similar reports were made by Mordi and Akanji (2012) and Adenirian et al., (2013). Peixoto Sobrinho et al., (2012) reported the presence of high frequency of flavonoids, especially in the aerial parts of Cnidoscolus species and Yuan et al., (2007) reported isolation of fifteen flavonoids from Cnidoscolous texanus. Flavonoids are antioxidants that neutralize free radicals - unstable, disease-causing molecules - and have the potential to also protect against the development of heart disease. They have been shown to have antifungal activity in vitro (Galeotti et al., 2008). The potent antioxidant activity of flavonoids reveals the ability to scavenge hydroxyl radicals, superoxide anions and lipid peroxy radicals, this may be the most important function of flavonoids (Alan and Miller, 1996). They also induce mechanisms that may kill cancer cells and inhibit tumour invasion (Williams et al., 2004). The sole greenish color of this leafy vegetable substantiates the fact that flavonoids contribute to the brilliant multicolor for most plants (Sofowora,1993).

A large amount of saponins were also detected in the ethanolic extract of Cnidoscolus aconitifolius leaves. Saponins have been shown to possess both beneficial (cholesterol lowering) and deleterious (cytotoxic; permeabilization of the intestines) properties. (Price et al., 1987; Oakenful and Sidha, 1989).

Table1. Phytochemical compositions of fresh leaves of Cnidoscolus aconitifolius

\begin{tabular}{|l|l|l|}
\hline $\begin{array}{l}\text { Phytochemical } \\
\text { Constituents }\end{array}$ & $\begin{array}{l}\text { Ethanolic extract } \\
\text { [mg/100g fresh leaves] }\end{array}$ & $\begin{array}{l}\text { Water extract } \\
\text { [mg/100g fresh leaves] }\end{array}$ \\
\hline Phlobotannins & 67 & \\
\hline Steroids & 38 & \\
\hline Phenols & 11.6 & \\
\hline Anthraquinones & 59 & \\
\hline Cyanogenic glycosides & & 24 \\
\hline Saponins & 3900 & \\
\hline Flavonoids & 1200 & \\
\hline Alkaloid & 490 & \\
\hline Tannin & & 236 \\
\hline Oxalate & & 873 \\
\hline
\end{tabular}

Price et al., (1989) and Trease and Evans (1989) have shown saponins to have immense significance as antihypercholesterol, hypotensive and cardiac depressant agent, suggesting the suitability of the plant in this respect. Studies have illustrated the beneficial effect on blood cholesterol levels, cancer bone health and stimulation of the immune system.

An appreciable amount of alkaloids was obtained from the ethanolic extract. Alkaloids have been associated with medicinal uses for centuries, and one of the common biological properties is their cytotoxicity[Nobori et al.,1994].Alkaloids are naturally occurring compounds commonly found to 
have antimicrobial properties, due to their ability to intercalate with DNA of the micro-organism (Kasolo et al., 2010). This could be responsible for their much acclaimed medicinal value. Alkaloids have been implicated for its detoxifying and antihypertensive properties (Trease and Evans, 1989; Zee-cheng, 1997). Several workers have reported the analgesic (Antherden, 1969), antispasmodic and antibacterial (Stray, 1998) properties of alkaloids. Phlobotannins were also detected in the ethanolic extract. This report is however, in contrast with the report of Awoyinka et al., (2007). The presence of phlobotannins suggests the diuretic property of the plant [Okuda,1990].The foregoing would suggest the possible utilization of $C$. aconitifolius as diuretic agent. Anthraquinones were found present in the ethanolic extract, though the therapeutic applications of these metabolites are vaguely understood (Trease and Evans, 1997; Sofowora, 1993).

Tannins were detected in the water extract (Table 1). Tannins are polyphenols that are obtained from various parts of different plants belonging to multiple species. The presence of tannins suggests the ability of this plant to play a major role as antidiarrhoec and antihaemorrhagic agent (Asquith and Butler, 1986). The healing and anti-inflammatory activities popularly attributed to Cnidoscolus spp. are strongly associated with its tannins content (Araujo et al., 2008). A little amount of phenols were found in the ethanolic extract. This is in agreement with the report of Mordi and Akanji (2011). Phenols are strong antioxidants which prevent oxidative damage to biomolecules such as DNA, lipids and proteins which play a role in chronic diseases such as cancer and cardiovascular diseases. Plant phenols may interfere with all stages of their cancer process, potentially resulting in a reduction of cancer risk (Hollman, 2011).

Cyanogenic glycosides were detected in the water extract of fresh leaves of Cnidoscolus aconitifolius in this study. Kuti and Torres (1996) reported the presence of toxic hydrocyanic glycosides in the raw leaves of tree spinach; however, cooking which is essential inactivates the toxic compound. Arthur (2012) also reported that uncooked Chaya leaves contain Cyanogenic glucosides (linamarin) that produce hydrogen cyanide upon tissue damage. The cooking time required to lower $\mathrm{HCN}$ to safe level is about 15 minutes. The presence of steroids in the ethanolic extract is of great significance, due to their relationship with such compounds as sex hormones (Okwu, 2001). Steroids have been reported to have antibacterial properties (Raquel, 2007). Some plant steroids are also useful for their effects when consumed by human beings, because their presence reduce the amount of cholesterol in the bloodstream (Wisegeek, 2013).

Oxalates were also found present in the water extract(Table 1). Oxalate occurs in many plants where it is synthesized via incomplete oxidation of carbohydrates. Many metal ions form insoluble precipitate with oxalates, a prominent example being calcium oxalate, the principal constituents of the most common kind of kidney stone (Wikipedia, 2014). The biological roles of calcium oxalate crystal formation in plant growth and development include high-capacity calcium regulation, protection against herbivores and tolerance to heavy metals, Nakata, (2012). Oxalates are toxic to the kidneys, because they form oxalic and crystals that do not dissolve and can be precipitated in many parts of the body including the brain. They cause damage to the kidney, arteries, stomach, etc (Botanical Online, 2014). The role of oxalates in the human body is not clearly understood.

\subsection{Proximate Analysis}

The result of the proximate analysis of fresh leaves of Cnidoscolus aconitifolius is presented in Table 2. It reveals that the fresh leaves contain high $(5.11 \%)$ crude protein $(82.45 \%)$ moisture $(2.50 \%)$ crude fibre $(1.80 \%)$, crude fat and $6.54 \%$ carbohydrate. The result is within the range reported by Kuti and Torres (1996), Ross-Ibarra and Molina-Cruz (2002), and Jansen (2014). It shows that the fresh leaves are good source of protein, thus supporting previous reports by Kuti and Konoru (2004).

Table2. Proximate composition of fresh leaves of Cnidoscolus aconitifolius

\begin{tabular}{|l|l|}
\hline Parameter. & Composition (\%) \\
\hline Crude fat content & 1.80 \\
\hline Crude fibre content & 2.50 \\
\hline Crude protein content & 5.11 \\
\hline Ash content & 1.60 \\
\hline Moisture content & 82.45 \\
\hline Carbohydrate content & 6.54 \\
\hline
\end{tabular}




\subsection{Mineral and Vitamin Analyses}

The results of the mineral and vitamin analyses, as presented in Tables 3 and 4, show that the fresh leaves of Cnidoscolus aconitifolius contain appreciable amounts of minerals and vitamins essential for human growth and maintenance. They are relatively high in potassium $(102 \mathrm{mg} / 100 \mathrm{~g})$, Calcium $(30.9 \mathrm{mg} / 100 \mathrm{~g})$, Iron $(4.7 \mathrm{mg} / 100 \mathrm{~g})$, Ascorbic acid $(142.11 \mathrm{mg} / 100 \mathrm{~g})$ and also contain Vit A (Carotene) $(13.10 \mathrm{mg} / 100 \mathrm{~g}), \quad$ B6 (pyridoxine) $\quad(1.34 \mathrm{mg} / 100 \mathrm{~g}), \quad$ B9 $\quad$ (Folic acid) $\quad(1.06 \mathrm{mg} / 100 \mathrm{~g}), \quad$ B12 (Cyanocobalamin) $(0.13 \mathrm{mg} / 100 \mathrm{~g})$.

Kuti and Torres (1996) reported that the levels of Chaya leaf nutrients are two to threefold greater than most edible leafy-green vegetables. In terms of the average nutritive value (ANV), Chaya leaf (14.9) is by far superior to other leafy, green vegetables such as spinach (6.4), Amaranth (1.3), Chinese cabbage (7.0) and Lettuce (5.4) (Grubben, 1978). While some edible, leafy green vegetables are usually good sources of mineral macronutrients (Lavender, 1990), Chaya leaf furnishes appreciable quantities of several of the essential mineral macronutrients of several of the essential mineral macronutrients of necessary for human health maintenance. For example, potassium has been shown to be an important mineral nutrient in the control of hypertension and in the reduction of risks of stroke (National Research Council, 1989). Calcium is important for ossification and iron is necessary for normal hematopoiesis (Hodges et al., 1978).

Table3. Vitamin compositions of fresh leaves of Cnidoscolus aconitifolius

\begin{tabular}{|l|l|}
\hline Vitamins & Composition [mg/100g fresh leaves] \\
\hline Vitamin A (Carotene) & 13.10 \\
\hline Vitamin $\mathrm{B}_{6}$ (Pyridoxine) & 1.34 \\
\hline Vitamin $\mathrm{B}_{9}$ (Folic acid) & 1.06 \\
\hline Vitamin $\mathrm{B}_{12}$ (Cyanocobalamin) & 0.13 \\
\hline Vitamin C (Ascorbic acid) & 142.11 \\
\hline
\end{tabular}

Table4. Mineral compositions of fresh leaves of Cnidoscolus aconitifolius

\begin{tabular}{|l|l|}
\hline Minerals. & Composition [mg/100g fresh leaves] \\
\hline Magnesium & 23 \\
\hline Potassium & 102 \\
\hline Calcium & 30.9 \\
\hline Phosphorus & 22 \\
\hline Iron & 4.7 \\
\hline Copper & 0.5 \\
\hline Manganese & 3.2 \\
\hline Zinc & 0.3 \\
\hline Sodium & 21 \\
\hline
\end{tabular}

Other authors (Booth et al., 1992; Jansen, 2004, and Arthur, 2012), have also reported on the rich, nutritional compositions of Cnidoscolus aconitifolus. The presence of Vitamins $\mathrm{B}_{6}, \mathrm{~B}_{9}$, and $\mathrm{B}_{12}$, as well as iron in the fresh leaves of Cnidoscolus aconitifolius, as reported in this study (Tables 3 and 4) support the use of these leaves as a blood builder in some parts of South - East Nigeria, where it has also been nick-named "Blood". Folic acid $\left(\mathrm{B}_{9}\right)$ and cyanocobalamin $\left(\mathrm{B}_{12}\right)$ are the two essential vitamins required for optimum red blood cell formation and this proper maturation. Vitamin $\mathrm{B}_{12}$ works closely with Vitamin $\mathrm{B}_{9}$, also folate or folic acid, to help make red blood cells; and to help iron work better in the body (Ehrlich, 2011).

Vitamin $B_{12}$ is an especially important vitamin air maintaining healthy nerve cells, and it helps in the production of DNA and RNA, the body's genetic material. Vitamins $\mathrm{B}_{12}, \mathrm{~B}_{6}$ and $\mathrm{B}_{9}$ work together to control blood levels of the amino acid "homocysteine". High levels of homocysteine are associated with heart diseases (Ehrlich, 2011).

Other vitamins detected in the leaf samples in this study are Vitamins A and C[Table 3].Vitamin A has several potential preventive and therapeutic uses. Vitamin A is an important "medicine" for the immune system. It keeps skin and mucous membrane cells healthy. This vitamin is particularly helpful in diseases caused by viruses. Measles, respiratory viruses and even Human Immune Deficiency Virus (HIV), the virus that causes AIDS, may retreat in the presence of vitamin A. Vitamin A fights cancer by inhibiting the production of DNA in cancerous cells. It slows down 
tumour growth in established cancer and may keep leukaemia cells from dividing (Brett, 2013). Vitamin C (or ascorbic acid) is essential to a healthy diet, as well as being a highly effective antioxidant acting to lessen oxidative stress (Wikipedia, 2014). There is an interesting ability of ascorbic acid, as an antioxidant, to prevent or at least minimize the formation of carcinogenic substances from dietary material (Hunt et al., 1980). This vitamin can also be used for the treatment of common cold and other diseases like prostrate cancer (Okwu and Okwu, 2004; Okwu and Okeke, 2003).

\section{Conclusion}

The phytochemical analysis of the fresh leaves of Cnidiscolus aconitifolius revealed the presence of saponins, flavonoids, alkaloids, phlobotannins, steroids, anthraquinone and phenols in the ethanolic extract and the presence of oxalate, tannins and cynanogenic glycosides in the water extract. These bioactive compounds may contribute to the reputed medicinal efficacy of the plant. The proximate analysis depicted/showed that the fresh leaves have high protein content. The mineral and vitamin analyses revealed that the fresh leaves of Cnidoscolus aconitifolius contain appreciable amounts of essential minerals/ macronutrients including magnesium, potassium, calcium, phosphorus, iron, copper, manganese, zinc and sodium and vitamins $\mathrm{A}, \mathrm{B}_{6}, \mathrm{~B}_{9}, \mathrm{~B}_{12}$, and $\mathrm{C}$. The presence of vitamins $\mathrm{B}_{6}$, $\mathrm{B}_{9}, \mathrm{~B}_{12}$, and Iron, suggest the use of the leaves as a blood builder.

Cyanogenic glycosides that produce toxic hydrogen cyanide upon tissue damage were also detected in the fresh leaves. However, cooking which is essential before consumption inactivates the toxic compounds.

Thus, results from this study show that Cnidoscolus aconitifolius is a nutritive, green vegetable and can be used as a medicinal plant. Being underexploited its commercial cultivation and use is strongly encouraged.

Further studies are recommended to isolate, characteristics are elucidate the structures of bioactive compounds contained in the leaves to elucidate their mechanism of action and use in industrial drug formulations.

\section{REFERENCES}

Abdala-Roberts L and Parra-Tabla V (2005). Artificial defoliation induces Trichome production in the Tropical shrub Cnidoscolus aconitifolius (Euphorbiaceae). Biotropica 37(2): 251 - 257.

Adeniran OI, Olajide OO, Igwemmar NC and Orishadipe AT (2013). Phytochemical constituents, antimicrobial and antioxidant potentials of tree spinach (Cnidoscolus aconitifolius (Miller) I.M. Johnston). Journal of Medicinal Plants Research. Vol 7 (19): 1317 - 1322.

Agomuo EN, Amadi BA, Chikezie PC and Ibegbulem CO (2002). Basic Analytical and Research Methods in Biochemistry. Supreme Publishers, Owerri. Pp $104-113$.

Alan L and Miller ND (1996). Antioxidant flavonoids, structure, function and clinical usage. Alt. Med. Rev., 1: 103 - 111.

Antherden LM (1969).Textbook of Pharmaceutical Chemistry, $8^{\text {th }}$ ed. Oxford University Press. London Pp. 813 - 814.

AOAC (1984). Official Methods of Analysis of the Association of Analytical Chemists. $14^{\text {th }} \mathrm{Ed}$. Assoc. Official Anal. Chem., Arlington, VA.

AOAC (1990). Standard Official Methods of Analysis of the Association of Analytical Chemists. $16^{\text {th }}$ Ed. Arlington V.A. U.S.A.

AOAC (2005). Official Methods of Analysis of the Association of Official Analytical Chemists. $18^{\text {th }}$ Ed. Gaithersburg. M.D.

Araujo TAS, Alencar NL, Amorim ELC and Albuquerque UP (2008). A new approach to study medicinal plants with tannins and flavonoids contents from the local knowledge. J. Ethnopharmacol. 120: $72-80$.

Arthur LJ (2012). Chaya Mayan Tree Spinach Cabbage Star (Cnidoscolus aconitifolius (Mill). I.M. Johnst. 1923 spp. aconitifolius http://www.arthurleej.com/p-o-m-jan12.html. Accessed $10^{\text {th }}$ July 2013, 11:30pm.

Asquith TN and Butler LG (1986). Interaction of condensed Tannins with selected proteins. Phytochem., 25 (7): $1591-1593$. 
Atuahene CC, Poku-Prempeh B, and Twun G (1999). The nutritive values of Chaya leaf meal (Cnidoscolus aconitifolius), studies with broilers chicken. Animal Feed Sci. Technol. 77: 163 172.

Awoyinka OA, Balogun IO, and Ogunnowo AA (2007). Phytochemical screening and in vitro bioactivity of Cnidoscolus aconitifolius (Euphorbiacea). J. Med. Plants. Res. 1: 63 - 65.

Barakate MZ, Shehab SK, and El Sadr MM (1955). A new Titrimetric method for the determination of ascorbic acid. Royal Society of Chemistry 80: $828-833$.

Booth S, Bressani R, and Johns T (1992). Nutrient content of selected indigenous leafy vegetable consumed by Kekchi people of Alta Verapaz, Guatemala. J. Food Compos. Anal. 5: 25 - 34.

Botanical Online (2014). Oxalate. Retrieved from www.botanical-online.com/english/oxalates.com. Accessed June 26 $6^{\text {th }}, 2014$.

Brett JND (2013). Benefits of Vitamin A. Consumer Guide (R). Publications International Ltd. http://health.howstuffworks.com/wellness/food-nutrition/vitamin-supplements/benefits-ofvitamin-a.html. Accessed $16^{\text {th }}$ October, 2013. 8:16pm.

Bullock SH (1982). Componentes fenológicos del sisterna de entrecruzamiento monóico de Cnidoscolus spinosus (Euphorbiaceae) en Jalisco. Bol. Soc. Bot. Mex. 42: 1 - 9.

Dong CX, Hayashi K, Lee JB and Hayashi T (2010).Characterization of structures and antiviral effects of polysaccharides from Portulaca oleracea L. Chem. Pharm. Bull. 58(4): 507 - 510.

Donkoh A, Kese AG, and Atuahene CC (1990). Chemical composition of Chaya leaf meal (Cnidoscolus aconitifolius) and availability of its amino acids to chicks. Anim. Feed Sci. Technol. 30: $155-162$.

Ehrlich SD (2011). Vitmain $B_{12}$ (Cobalamin) Veri Med Healthcare Network. http://umm.edu/health/medical/altmed/supplement/vitamin-b12-cobalamin. Accessed $24^{\text {th }}$ October, 2013. 12:12pm.

Elvin - Lewis P, Memory FL and Walter H (1977). Medicinal Botany: Plants Affecting Man's Health. Wiley,New York. ISBN :0-471-53320-3.

Galeotti F, Barile E, Curir P, Dolci M and Lanzotti V (2008). Flavonoids from carnation (Dianthus caryophyllus) and their antifungal activity. Phytochem. Lett., 1: 44.

Grubben GJH (1978). Tropical vegetables and their genetic resources. Int. Board Plant Genetic Resource, FAO - UN. Rome. Italy.

Harborne JB (1973). Phytochemical Methods: A Guide to Modern Techniques of Plant Analysis. Chapman A. \& Hall. London. Pp 279.

Hodges RE, Sauberlich HE, Canham JE, Wallace DL, Rucker RB, Mejia LA and Mohanram M (1978). Hematopoietic studies in vitamin A deficiency. Am. J. Clin. Nutr, 31: $876-885$.

Hollman PC (2001). Evidence for health benefits of plant phenols: Local or systemic effects? J. Sci. Food Agric., 81: 842 - 852.

Hunt S, Goff JL, and Holbrook J (1980). Nutrition, Principles and Chemical Practices. John Wiley and Sons. New York. Pp $49-52$.

Jansen PCM (2004). Cnidoscolus aconitifolius (Mill) I.M. Johnst, In: Grubben GJH \& Denton OA (Editors), PROTA 2: Vegetables/Legumes. (CD-ROM). PROTA, Wageningen, Netherlands.

Jensen SA (1997). Chaya, the Mayan miracle plant. J. Food. Sci, 51: 234 - 244.

Kasolo JN, Gabriel S, Bimenya OJ and Ogwal-Okeng JW (2010). Phytochemicals and uses of Moringa oleifera leaves in Uganda rural communities. J. Med. Plants Res., 4 (9): 753 - 757.

Kirk RS and Sawyer R (1998). Pearson's Composition and Analysis of Food. $9^{\text {th }}$ Ed. Churchill Livingstone. Edinburgh. Pp $17-20$.

Kuti JO and Konoru HB (2004). Antioxidant capacity and phenolic content in leaf extracts of Tree Spinach (Cnidoscolus spp). Journal of Agricultural and Food Chemistry. 52 (1): 117 - 121.

Kuti JO and Torres ES (1996). Potential nutritional and health benefits of tree spinach. In: Janick .J. (ed). Progress in new crops. ASHS Press, Arlington, V.A

Lavender OA (1990). Fruit and vegetable contribution to dietary mineral intake in human health and disease. Hort Science 25: 1486 - 1488. 
Lewis J (1974). Determination of Anthraquinone. J. Ind. and Eng. Chem. Vol 10. Pp 425.

Loliger J (1991). The use of antioxidants in Food. In: Auroma OI, Halliwell B [Eds]. Free radicals and Food additives. Taylor and Francis.London.pp121.

Lookadoo SE and Pollard AJ (1991). Chemical contents of stinging trichomes of Cnidoscolus texanus. J. Chem. Ecol. 17(9): 1906 - 1916.

Mordi JC and Akanji MA (2012). Phytochemical screening of the Dried leaf extract of Cnidoscolus aconitifolius and Associated changes in liver enzymes induced by its administration in Wistar Rats. Current Research Journal of Biological Sciences. 4(2): 153 - 158.

Munro A and Bassir D (1969). Oxalates in Nigeria Vegetables. W. Afr. J. Biol. Appl. Chem. 12: 14 $-18$.

Nakata PA (2012). Plant calcium oxalate crystals formation, function and its impact on Human health. Front. Biol. Vol. 7(3): $254-266$.

Nabori T, Miurak K, Wu DJ, Takabayashik LA and Carson DA (1994). Deletion of Cyclindependent Kinase - 4 inhibitor gene in multiple human cancers. Nature, 46: 753 - 756.

National Research Council [1989]. Diet and Health. National Academy Press, Washington, D.C.

Oakenful D and Sidhu GS(1989). Saponins In: Cheeke, P.R. (Ed) Toxicants of Plant Origin. Academic Press, New York. 2: 78 - 113.

Okuda TY (1991). Chemistry and Biological Activity of Tannins in Medicinal Herbs. Diamond Books.London.pp $897-900$.

Okwu DE (2001). Evaluation of Chemical composition of Indigenous Spices and Flavouring Agents. Global J. Pure Appl. Sci. 7(3): 455 - 59.

Okwu DE and Okeke O(2003). Phytochemical screening and Mineral composition of chewing sticks in South - Eastern Nigeria. Global J. Pure Appl. Sci. 9: 235 - 38.

Okwu DE and Okwu ME (2004). Chemical composition of Spindias mombin plants. J. Sustain Agric. Environ. 6(2): 140 - 147.

Pearson D (1976). The Chemical Analysis of Foods. 7th Edn. Livingstone, London. Churchill. p572

Peixoto Sobrinho TJS, Castro VTNA, Saraiva AM, Almeida DM, Tavares EA, Pisciottano MNC and Amorim ELC (2012). Phytochemical screening and antibacterial activity of four Cnidoscolus species (Euphorbiacea) against standard strains and clinical isolates. J. Med. Plants Res. 6(12): $3742-3748$.

Pollard AJ and Briggs D (1984). Genecological studies of Urtica dioica. L. III. Stinging hairs and plant-herbivore interactions. New Phytol. 97: 507 - 522.

Price KR, Johnson TI and Fenwick GR (1987). The Chemistry and Biological significance of Saponins in foods and feedstuffs. CRC Crit. Rev. Food Sci. Nutr. 26: $27-135$.

Raquel FE, Paul BS and Richard ME (2007). Bacterial lipid composition and antimicrobial efficacy of cationic steroid compounds. Biochemica et Biophysica Acta. 1768(10): 2500-2509.

Ross-Ibarra J and Molina-Cruz A (2002). The ethnobotany of Chaya (Cindoscolus aconitifolius spp. aconitifolius Breckon): a nutritious Maya vegetable. Economic Botany. 56(4): 350 - 365.

Rowe L (1994). Plant guards secret of good health. Valley Morning Star. Sept 4th, 1994. Pp Al, A2.

Sofowora A (1993). Medicinal Plants and Traditional Medicines in Africa. Chichester John Wiley \& Sons, New York. Pp: $97-145$.

Trease GE and Evans WC (1989). Pharmacology. 11th Edn., Bailliere Tindall Ltd., London, Pp: 60 75.

Wikipedia (2014). Vitamin C.Retrieved from: en.wikipedia.org/wiki/Vitamin C. Accessed 9th May, 2014

Wikipedia (2014). Oxalate. Retrieved from: en.wikipedia/wiki/Oxalate. Accessed 9th June, 2014. $4: 10 \mathrm{pm}$

Wisegeek (2013). What are Plant Steroids. Retrieved from: www.wisegeek.com/what-are-plantsteroids.htm. Accessed 29th October, 2013. 3:31pm

Williams RJ, Spencer JP and Rice-Evans C (2004). Flavonoids: antioxidants or signalling molecules? Free Radical Biol Med., 36(7): 838 - 849.

Yuan, W, Li S, Ownby S, Zhang Z, Wang P, Zhang W and Beasley RS (2007). Flavonoids, Coumarins and triterpenes from the aerial parts of Cnidoscolus texanus. Planta Med. 73: 13041308.

Zee - Cheng RK (1997). Anticancer research on Loranthaceae plants. Drugs Future, 22(5): 515-530. 